\title{
Comparative evaluation of baseline characteristics of HIV mono infected and HIV/HBV co infected cohort in eastern India
}

\author{
Jayeeta Sarkar ${ }^{1 *}$, Debraj Saha², Bibhuti Saha', Bhaswati Bandyopadhyay ${ }^{1}$, Runu Chakrabarty², \\ Subhasish Kamal Guha' \\ From 2nd International Science Symposium on HIV and Infectious Diseases (HIV SCIENCE 2014) \\ Chennai, India. 30 January - 1 February 2014
}

\section{Background}

India has the third largest estimated number of HIV infected people and 40 million individuals in India are estimated to be Hepatitis B virus infected. In comparison to HBV mono-infection, the course of chronic HBV infection is more accelerated in HIV/HBV co-infected subjects. We analyzed the baseline characteristics of the HIV/HBV co-infected and HIV mono-infected patients.

\section{Methods}

Between July 2011 and January 2013, a total number of 1331 HIV-seropositive treatment naïve individuals, enrolled in the ART Centre of Calcutta School of Tropical Medicine were screened for HBsAg. A number of $1253 \mathrm{HIV}$ mono-infected and $78 \mathrm{HIV} / \mathrm{HBV}$ co-infected patients were characterized. The co-infected patients were evaluated for $\mathrm{HBeAg}$ and anti $\mathrm{HBe}$ antibody by ELISA. HBV DNA was detected by nested PCR amplification followed by HBV genotype determination.

\section{Results}

The median age (35 years) was similar in HIV monoinfected and HIV/HBV co-infected group. The proportion of advanced HIV disease (WHO clinical stage III \& IV) was more in HIV/HBV co-infected patients (37.1\% vs. $19.9 \%)$ than HIV mono-infected subjects. The co-infected subjects had significantly higher serum bilirubin, ALT, alkaline phosphatase, creatinine and ALT/platelet ratio index. CD4 count was non significantly lower in co-infected patients. Majority (61.5\%) were $\mathrm{HBeAg}$ reactive with higher HBV DNA $(p=0.0001)$ and APRI $(p=0.04)$ as compared to

\footnotetext{
* Correspondence: jayee.6jan@gmail.com

${ }^{1}$ Calcutta School of Tropical Medicine, Kolkata, West Bengal, India

Full list of author information is available at the end of the article
}

HBeAg negative (38.5\%) patients. Genotype HBV/D (71.7\%) was the predominant genotype followed by HBV/A (19.4\%) and HBV/C (8.9\%) among the co-infected patients from eastern India.

\section{Conclusion}

HIV/HBV co-infection warrants long term prospective study on immune recovery, HIV and HBV viral replication, and hepatotoxicity.

\section{Authors' details}

'Calcutta School of Tropical Medicine, Kolkata, West Bengal, India. ${ }^{2}$ ICMR Virus Unit, Kolkata, ID \& BG Hospital Campus, Kolkata, West Bengal, India.

Published: 27 May 2014

doi:10.1186/1471-2334-14-S3-P14

Cite this article as: Sarkar et al:: Comparative evaluation of baseline characteristics of HIV mono infected and HIV/HBV co infected cohort in eastern India. BMC Infectious Diseases 2014 14(Suppl 3):P14.

Submit your next manuscript to BioMed Central and take full advantage of:

- Convenient online submission

- Thorough peer review

- No space constraints or color figure charges

- Immediate publication on acceptance

- Inclusion in PubMed, CAS, Scopus and Google Scholar

- Research which is freely available for redistribution Submit your manuscript at
www.biomedcentral.com/submit () Biomed Central 